\title{
Predictive Value of Clinical and Electrophysiological Variables in Patients with Chronic Chagasic Cardiomyopathy and Nonsustained Ventricular Tachycardia
}

\author{
Rose Mary Ferreira Lisboa da Silva, Maria Zildany Pinheiro Távora, Fernando Antônio Aquino Gondim, \\ Niraj Metha, Vanderlei Mitsuo Hara, Angelo Amato Vincenzo de Paola
}

São Paulo, SP - Brazil

\begin{abstract}
Objective - Risk stratification of patients with nonsustained ventricular tachycardia (NSVT) and chronic chagasic cardiomyopathy (CCC).
\end{abstract}

Methods - Seventy eight patients with CCC and NS$V T$ were consecutively and prospectively studied. All patients underwent to 24-hour Holter monitoring, radioisotopic ventriculography, left ventricular angiography, and electrophysiologic study. With programmed ventricular stimulation.

Results - Sustained monomorphic ventricular tachycardia (SMVT) was induced in 25 patients (32\%), NSVT in $20(25.6 \%)$ and ventricular fibrillation in 4 (5.1\%). In 29 patients (37.2\%) no arrhythmia was inducible. During a 55.7-month-follow-up, 22 (28.2\%) patients died, 16 due to sudden death, 2 due to nonsudden cardiac death and 4 due to noncardiac death. Logistic regression analysis showed that induction was the independent and main variable that predicted the occurrence of subsequent events and cardiac death (probability of 2.56 and 2.17 , respectively). The Mantel-Haenszel chi-square test showed that survival probability was significantly lower in the inducible group than in the noninductible group. The percentage of patients free of events was significantly higher in the noninducible group.

Conclusion - Induction of SMVT during programmed ventricular stimulation was a predictor of arrhythmia occurrence cardiac death and general mortality in patients with CCC and NSVT.

Key words: Chagasic heart disease, nonsustained ventricular tachycardia, electrophysiologic study

Universidade Federal de São Paulo - Escola Paulista de Medicina Mailing address: Rose Mary Ferreira Lisboa da Silva - Rua Napoleão de Barros, 593 - 04024-002 - São Paulo, SP - Brazil - E-mail: eletrof@ uol.com.br
Ventricular arrhythmias have been related to subsequent mortality in patients with heart disease encouraging studies on risk stratification and management of complex ventricular arrhythmias ${ }^{1-4}$. The importance of the prognosis is influenced by specific clinical manifestations and their severity, and the impact of NSVT on valvular heart disease, congenital heart disease, cardiomyopathy and coronary disease $^{5}$. In our environment, $\mathrm{CCC}$ has already been reported because of its prevalence, pathogenesis and prognosis. Studies were mostly related to conduction disturbances, syncope investigation, and efficacy of antiarrhythmic drugs in patients with sustained ventricular tachycardia ${ }^{6-16}$.

Few studies have been conducted in patients with CCC and complex ventricular arrhythmias, and hard data about this subject are lacking. The problems of the studies that have been conducted are related to population heterogeneity, different protocols related to programmed ventricular stimulation and no correlation analysis between clinical and laboratory variables ${ }^{17-21}$.

The objectives of our study are to analyze clinical variables (sex, age, presence of syncope), laboratory evaluation (conduction disturbances, complex ventricular arrhythmias, segmental abnormalities, ejection fraction) and electrophysiologic studies (induction of sustained monomorphic ventricular tachycardia-SMVT) in patients with CCC and NSVT for risk stratification, and survival study of this high risk population.

\section{Methods}

Seventy-eight patients with CCC and NSVT from the Clinical Cardiology Division, Hospital São Paulo, Escola Paulista de Medicina, of the Federal University of São Paulo were consecutively studied. Inpatients were admitted due to either syncope or near syncope or due to cardiac failure, or all of these. Nonsustained ventricular tachycardia was recorded on electrocardiogram or 24-hour Holter monitoring. Diag- 
nostic criteria for CCC included serologic tests and presence of heart disease, through history and physical examination, 12-lead electrocardiogram, chest roentgenogram and echocardiogram. Patients with decompensated congestive heart failure, coronary heart disease, cardiomyopathy of any etiology, pregnancy and serious chronic disease were excluded. We studied 45 male and 33 female patients with ages ranging from 21 to 68 years (mean $46.4 \pm 10.7$ ).

All patients underwent clinical and laboratory evaluation, including serological reactions (Machado Guerreiro immunofluorescence), 12-lead electrocardiogram, chest roentgenogram, two-channel 24-hour Holter monitoring, echocardiogram, radioisotopic ventriculography, left ventricular angiography and electrophysiologic study. All antiarrhythmic drugs were discontinued for at least 5 halflives and for 45 days if the drug was amiodarone. Patients older than 40 years also had coronary angiography performed by either the Sones or Judkins technique.

Electrophysiologic studies were performed with patient not sedated, by puncture of femoral right and left veins to position the electrode catheters, using the percutaneous modified Seldinger technique. A small amount of local anesthetic ( $2 \%$ solution of lidocaine hydrochloride) was infiltrated into the area. Catheters were inserted and positioned in the high right atrium, in contact with the septum until a His bundle potential was recorded, in the right ventricular apex and outflow tract, if it was necessary. During the study, a bolus of 2500U of heparin was administered followed by $1000 \mathrm{U} / \mathrm{h}$. After recording of A-H and H-V intervals, sinus node function, sinoatrial conduction time, sinus node recovery time and analysis of A-V conduction were performed. Programmed ventricular stimulation was performed in the right ventricular apex, during two pacing cycle lengths $(600$ and $450 \mathrm{~ms}$ ), beginning late in diastole and moved progressively earlier until ventricular refractoriness was reached. The extrastimulus was delivered after a train of 8 paced complexes. If a single extrastimulus (S2) did not induce SMVT, a second extrastimulus (S3) was added. Double extrastimuli were introduced starting with an S1-S2 interval 50ms greater than an effective ventricular refractory period and an S2-S3 interval equal to the S1-S2 interval. The S2-S3 coupling interval was shortened by $10 \mathrm{~ms}$ decrements until $\mathrm{S} 3$ became refractory, at which time $\mathrm{S} 2$ was decreased by $10 \mathrm{~ms}$ decrements until S3 evoked a response. This sequence was also repeated in the right ventricular outflow tract until both extrastimuli reached refractoriness or sustained ventricular tachyarrhythmias were induced. The induction was reproduced, except in cases of electric cardioversion. Stimulation was performed with impulses $1-2 \mathrm{~ms}$ in duration at twice the diastolic threshold.

All patients with SMVT were treated with amiodarone or sotalol. Diuretics, digitalis, angiotensin-converting enzyme inhibitors and antihypertensive therapy were administered according to indications.

Definitions: A) Ventricular tachycardia - three or more consecutive ventricular complexes at a rate of more than 100 beats/min; sustained ventricular tachycardia: tachycardia that lasted more than 30 seconds or when cardiovas- cular collapse was present; nonsustained ventricular tachycardia without cardiovascular collapse that ended spontaneously in less than 30 seconds; B) inducible ventricular tachycardia: six or more ventricular complexes induced by programmed electrical stimulation. If it lasted more than 30 seconds or if hemodynamic collapse occurred, it was defined as sustained; if not, it was defined as nonsustained; C) ventricular fibrillation: sustained ventricular arrhythmia with disorganized electric activity on ECG without distinct QRS complexes; D) sudden death: unexpected, nontraumatic, in patients with or without previous disease, occurring within an hour after the onset of symptoms. The victim should be well 24-hours before if death was not witnessed ${ }^{22}$;E) cardiac death: that caused by sudden death or due to heart failure; F) events: included cardiac death, spontaneous sustained ventricular tachycardia and recurrence of syncope.

Statistical analysis - The Chi-square test with Fisher's exact proportion was used to study a possible correlation between variables; the Mann-Whitney test was used to compare two independent groups; Wilcoxon's test was used to compare nondependent groups ${ }^{23}$ and the Mantel-Haenszel test ${ }^{24}$ was used for survival analysis between patients with SMVT, induced and noninduced. A $p$ value of $<0.05$ was considered significant and marked with a sign $(*)$. The results were analyzed using a stepwise logistic regression (program SAS Institute Inc. SAS/STAT User's Guide, Version 6).

\section{Results}

According to symptoms, 37 patients (47.4\%) had syncope, 57 had near syncope and 12 had chest pain. According to the functional classification of congestive heart failure (New York Heart Association), 38 patients (48.7\%) were in class I, $28(35.9 \%)$ in class II, 8 in class III and 4 in class IV. Only 2 patients had atrial fibrillation. Sixty-three patients $(80.8 \%)$ had conduction disturbances, atrioventricular block, fascicular blocks or bundle branch block. Twenty-four hour Holter monitoring recorded 11 and 1355 premature ventricular complexes/hour (median 203.5) and one and $2500 \mathrm{NSVT}$ (median 3.5) episodes. Ejection fraction varied from 0.10 to 0.80 (mean 0.47 , median 0.48 ). Twentyseven patients $(34.6 \%)$ had segmental abnormalities, which were located mainly in the apex (59\%). None of the patients had coronary lesions on cineangiography.

Electrophysiologic studies detected sinus node dysfunction defined by prolonged sinus node recovery time in 3 patients $(3.8 \%)$; HV interval was normal in 60 patients (76.9\%). These evaluations were not made in 8 patients with pacemakers.

Programmed ventricular stimulation induced SMVT in 25 patients $(32 \%)$, NSVT in $20(25.6 \%)$, ventricular fibrillation in $4(5.1 \%)$; in 29 patients noninducible ventricular arrhythmias (37.2\%) occurred. Utilization of 3 extrastimuli was necessary to induce SMVT in 17 patients $(68 \%)$. Electrical cardioversion was performed in 13 patients $(52 \%)$ with induced ventricular arrhythmias. Cycle length of SMVT varied from 130 to $320 \mathrm{~ms}$ (median $240 \mathrm{~ms}$, mean $228 \mathrm{~ms}$ ). 
Male gender $(48 \% x 12 \%)$, syncope $(47 \% \times 22 \%)$, age $(54 \times$ 45 years) conduction disturbances ( $40 \% \times 7 \%)$ and lower ejection fraction were significantly associated with induction of SMVT.

Clinical evaluation - Mean clinical follow-up was $55.7 \pm 37.7$ months (median 50.5), without a significant difference between inducible and noninducible groups. During follow-up 22 deaths (28.2\%) occurred, 16 (72.7\%) due to sudden death, 2 (9\%) due to nonsudden cardiac death, one due to stroke, one due to mesenteric thromboembolism, one due to arrhythmia and one due to sepsis. Spontaneous sustained ventricular tachycardia was noticed in 6 patients from the inducible group and one from the noninducible group $(\mathrm{p}=0.005)$. Laboratory induction had a positive predictive value of $24 \%$ and a negative predictive value of $98 \%$ for developing clinical SMVT.

Events were observed in 24 patients (sudden death in 16 , nonsudden cardiac death in 1, spontaneous SVT in 7 , and syncope recurrence in 3 patients). Episodes of spontaneous SVT occurred in patients with sudden death (3 patients) or nonsudden death (one patient). Events occurred more often in patients with conduction disturbances and in the inducible group. Cardiac death occurred more frequently in patients with low ejection fraction and also in the inducible group. A significant association existed between sudden or general mortality and SMVT induction (table I). Therefore, SMVT induction had a positive predictive value of $63 \%$ and a negative predictive value of $80 \%$ for occurrence of events. Cardiac mortality had a positive predictive value of $46 \%$ and a negative predictive value of $85 \%$.

Logistic regression analysis had higher probability of SMVT induction among men and a 2.74 higher induction probability for every 10 year increase in age. Induction was also significant, (2.58 times more frequent) for event occurrence and cardiac mortality (table II).

During a mean follow-up of $65.0 \pm 38.7$ months (median

\begin{tabular}{|lcccc|}
\hline \multicolumn{5}{|c|}{$\begin{array}{c}\text { Table I - Correlation between SMVT and event occurrence, } \\
\text { cardiac death (CD), sudden death (SD) and general } \\
\text { mortality (GM) }\end{array}$} \\
\hline Induction of SMVT & Events & $\mathrm{CD}$ & $\mathrm{SD}$ & $\mathrm{GM}$ \\
\hline Present & 15 & 11 & 10 & 12 \\
Absent & 9 & 7 & 6 & 10 \\
$\chi 2$ & $11.07^{*}$ & $7.74^{*}$ & $7.69^{*}$ & $6.03^{*}$ \\
\hline
\end{tabular}

\begin{tabular}{|c|c|c|c|}
\hline \multicolumn{4}{|c|}{$\begin{array}{l}\text { Table II - Regression analysis according to dependent variables: } \\
\text { SMVT induction, presence of events and cardiac mortality (CM), } \\
\text { confidence interval (CI) } 95 \%\end{array}$} \\
\hline \multicolumn{2}{|c|}{ Variable } & \multirow{2}{*}{ Odds ratio } & \multirow[t]{2}{*}{ CI $95 \%$} \\
\hline Dependent & Independent & & \\
\hline \multicolumn{4}{|l|}{ Induction } \\
\hline \multirow[t]{2}{*}{ SMVT } & Sex & 3.3 & $1.3-7.7$ \\
\hline & Age & 1.14 & $1.06-1.23$ \\
\hline Events & SMVT induction & 2.58 & $1.51-4.43$ \\
\hline $\mathrm{CM}$ & SMVT induction & 2.17 & $1.23-3.83$ \\
\hline
\end{tabular}

77), 4 patients with induced ventricular fibrillation to programmed ventricular stimulation did not have events.

Survival curves - Accumulated survival probability was related to general and cardiac mortality and to the proportion free of events from the whole population studied (table III).

The Mantel - Haenszel test was used to compare accumulated survival curves considering SMVT induction as a predictor of survival. Inducible and noninducible patients had significant differences related to general or cardiac death and event occurrence (table IV and figures I, II, III).

\section{Discussion}

Population characteristics - Chronic chagasic cardiomyopathy has a male predominance, with a progressive incidence from the third decade of life ${ }^{25}$. Seventy-eight chagasic patients with a mean age of $46.4 \pm 10.7$ years old were studied. Forty-five patients were males (57.7\%).

\begin{tabular}{|lccc|}
\hline \multicolumn{4}{|c|}{ Table III - Cumulative survival probability and percentage of } \\
patients free of cardiac events \\
\hline \multicolumn{4}{c|}{$\begin{array}{c}\text { Cumulated survival } \\
\text { probability }\end{array}$} \\
Time & General & Cardiac & Percent free \\
(months) & mortality & mortality & of events \\
\hline $0-12$ & 100 & 100 & 100 \\
$12-24$ & 91.7 & 93.2 & 93.1 \\
$24-36$ & 88.7 & 90.2 & 89.9 \\
$36-48$ & 83.9 & 87.0 & 86.7 \\
$48-60$ & 81.9 & 85.2 & 82.9 \\
$60-72$ & 81.9 & 85.2 & 80.7 \\
$72-84$ & 74.7 & 78.3 & 71.2 \\
$84-96$ & 63.6 & 70.7 & 63.2 \\
$96-108$ & 60.2 & 70.7 & 63.2 \\
$108-120$ & 50.6 & 63.8 & 44.4 \\
$120-132$ & 50.6 & 63.8 & 35.6 \\
\hline
\end{tabular}

\begin{tabular}{|c|c|c|c|c|c|c|}
\hline \multicolumn{7}{|c|}{$\begin{array}{l}\text { Table IV - Cumulative survival probability according } \\
\text { general mortality, cardiac mortality and percentage of } \\
\text { patients free of cardiac events in inducible (IND) and } \\
\text { noninducible (NI) patients }\end{array}$} \\
\hline \multicolumn{7}{|c|}{$\begin{array}{c}\text { Cumulated survival } \\
\text { probability }\end{array}$} \\
\hline \multirow[t]{2}{*}{$\begin{array}{l}\text { Time } \\
\text { (months) }\end{array}$} & \multicolumn{2}{|c|}{$\begin{array}{l}\text { General } \\
\text { mortality }\end{array}$} & \multicolumn{2}{|c|}{$\begin{array}{l}\text { Cardiac } \\
\text { mortality }\end{array}$} & \multicolumn{2}{|c|}{$\begin{array}{c}\text { Percent free } \\
\text { of events }\end{array}$} \\
\hline & IND & NI & IND & NI & IND & NI \\
\hline $0-12$ & 100 & 100 & 100 & 100 & 100 & 100 \\
\hline $12-24$ & 82.9 & 95.6 & 87.2 & 95.6 & 86.9 & 95.6 \\
\hline $24-36$ & 78.4 & 93.2 & 82.6 & 93.2 & 82.1 & 93.2 \\
\hline $36-48$ & 68.6 & 90.6 & 72.9 & 93.2 & 71.9 & 93.2 \\
\hline $48-60$ & 62.9 & 90.6 & 67.3 & 93.2 & 60.4 & 93.2 \\
\hline $60-72$ & 62.9 & 90.6 & 67.3 & 93.2 & 54.3 & 93.2 \\
\hline $72-84$ & 62.9 & 78.8 & 67.3 & 81.5 & 47.9 & 81.0 \\
\hline $84-96$ & 35.9 & 74.4 & 42.1 & 81.5 & 27.4 & 81.0 \\
\hline $96-108$ & 35.9 & 69.1 & 42.1 & 81.5 & 27.4 & 81.0 \\
\hline $108-120$ & 23.9 & 61.8 & 31.6 & 75.0 & 11.7 & 64.8 \\
\hline $120-132$ & & 61.8 & & 75.0 & & 50.4 \\
\hline$\chi^{2}$ & \multicolumn{2}{|c|}{$7.41^{*}$} & \multicolumn{2}{|c|}{$7.41 *$} & \multicolumn{2}{|c|}{$15.37 *$} \\
\hline
\end{tabular}




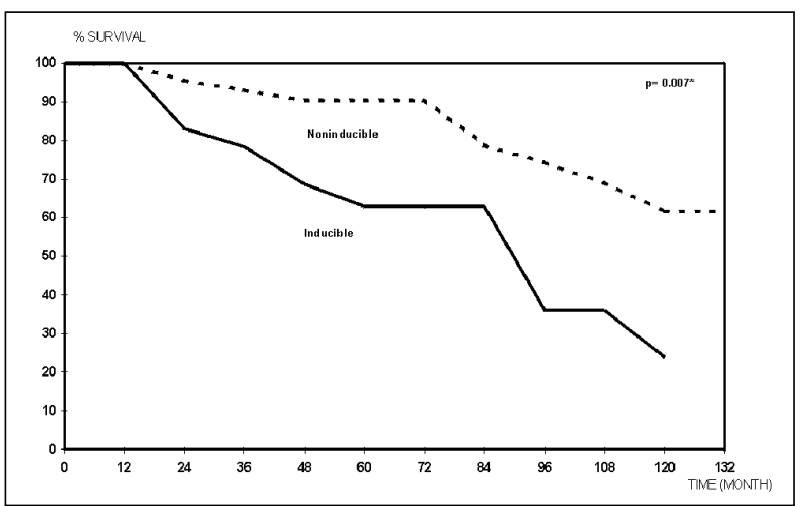

Fig. 1 - Total Mortality.

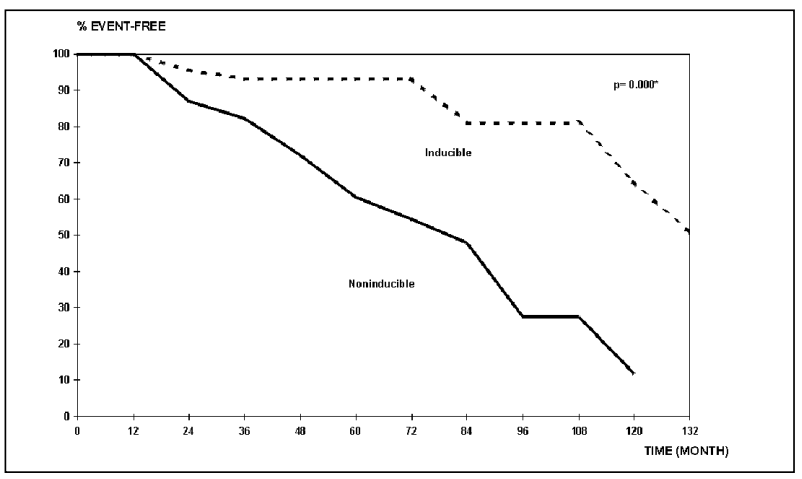

Fig. 2 -Events.

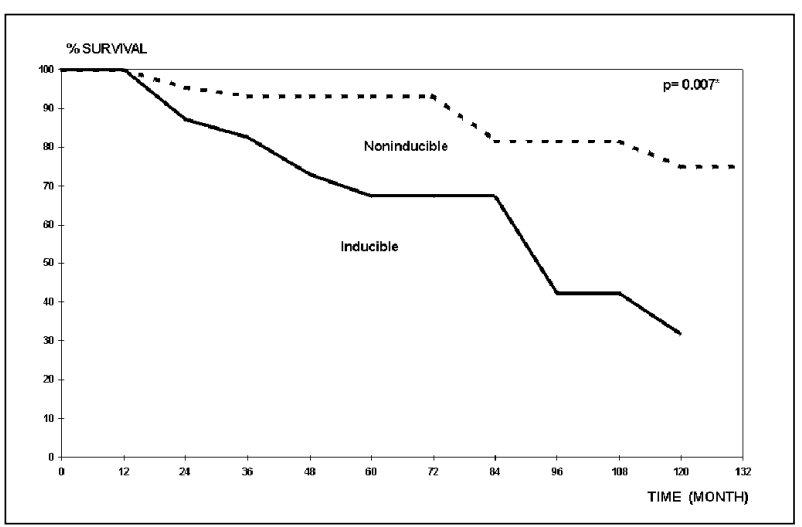

Fig. 3-Cardiac Mortality.

Conduction disturbances are present in 60 to $87 \%$ of patients with Chagas disease, and right bundle branch block with left anterior fascicular block is present in 16 to $39 \%$ of patients ${ }^{26-28}$. Our study population showed similar findings with $80.8 \%$ of conduction disturbances with predominance of right bundle branch block associated with left anterior fascicular block in $32 \%$ of patients. Sinus node dysfunction occurred in 3 patients $(3.8 \%)$. These data differ from that in the literature that reported an incidence ranging from 18 to $45 \%$ among patients with decompensated heart failure. His-Purkinje system dysfunction, corresponding to an increase in HV interval was found in 10 patients (12.8\%), and this finding was similar to the $13.5 \%$ reported by Benchimol $^{29}$.

In our study segmental abnormalities occurred in 27 patients $(34.6 \%), 59 \%$ in the apex. Reports of this finding in Chagas disease range between 30 to $93 \%{ }^{30-33}$.

Finally, like previous studies ${ }^{34-36}$, coronary disease was not detected by coronary angiography in any of the patients studied.

Correlation between clinical and laboratory variables In Brazil ${ }^{17-21}$, the induction rate of sustained ventricular arrhythmias in these patients' ranges from 0 to $32 \%$. This wide variation is probably due to population heterogeneity, which includes patients with isolated premature ventricular beats, NSVT, ejection fraction ranging from 0.34 to 0.62 and use of different ventricular stimulation protocols. Studies with chagasic patients including only patients with NSVT on 24hour Holter monitoring were only reported from our institution ${ }^{18,20}$. In the current study the induction rate was $32 \%$. Contrary to data in the literature ${ }^{37,38}$, in our study left ventricular dysfunction was not associated with male gender.

The influence of left ventricular dysfunction on ventricular arrhythmias has been thoroughly studied in coronary disease ${ }^{39,40}$ and in cardiac valve disease ${ }^{41}$ but not in dilated cardiomyopathy ${ }^{42,43}$. In our study, ventricular dysfunction was not related to premature ventricular beats, age or conduction disturbances of surface ECG. Santana ${ }^{44}$ reported that complex premature ventricular beats, especially NSVT, were associated with an increase in cardiothoracic index and functional class II. Carrasco ${ }^{37}$ studied 556 chronic chagasic patients using left ventricular angiography that showed that ventricular dysfunction and age were related to the presence of complex ventricular arrhythmias. Garzon ${ }^{45}$ reported that in 901 chagasic patients electrocardiographic abnormalities were associated with the presence of low ejection fraction.

In our results global left ventricular dysfunction was not associated with the presence of segmental abnormalities. Apical aneurysms were more common in patients with preserved left ventricular function than in dilated ventricles with global dysfunction ${ }^{46,47}$.

Sustained monomorphic ventricular tachycardia induction was predominant in males. The intensity of immunologic reaction leading to fibrosis may have been higher in males, intensively compromising the myocardium locally with a greater number of arrhythmogenic circuits as a consequence.

Logistic regression analysis has also shown greater probability of SMVT induction with age and an increase of more than two times for each 10 years of age.

Syncope was also a predictor of SMVT induction. Electrophysiological studies for syncope investigation in chagasic individuals found SMVT induction of $47 \%$ and $55 \%{ }^{12 a, 13}$.

Results in the literature ${ }^{48}$ have reported a controversial association between ventricular complexity and SMVT induction due to programmed ventricular stimulation. However, among chagasic patients, Mendonça ${ }^{14}$ reported lack of association between ventricular arrhythmias or NSVT with SMVT induction. These results are similar to ours. 
Correlation between ventricular dysfunction and SMVT induction was documented by Da Silva's study ${ }^{17}$ with 26 chagasic patients with frequent premature ventricular beats; by De Paola ${ }^{18}$ with 27 chagasic patients with NSVT with an induction rate of $19 \%$; and by Mendonça ${ }^{14}$ with 60 patients with NSVT, and $20 \%$ inducibility. The present study has also found significant correlation between ventricular dysfunction and SMVT induction.

Evidence suggests that in CCC spontaneous SVT uses as a reentrant circuit left ventricular areas of fibrosis or aneurysms, mainly in the inferolateral wall followed by the septum and apex ${ }^{49,50}$. Spielman ${ }^{51}$ reported induction of ventricular tachycardia and ventricular fibrillation among patients with ventricular arrhythmias who had at least one akinetic or dyskinetic zone revealed by radioisotopic ventriculography. Buxton ${ }^{52}$ has also reported that in patients with coronary artery disease, ventricular tachycardia was induced more frequently in the presence of left ventricular aneurysm. In our study, no significant association existed between SMVT induction and segmental abnormalities. De Paola ${ }^{53}$ found a significant association between the presence of left ventricular aneurysms and spontaneous SVT in chagasic patients; but in that study none of the chagasic patients with NSVT had left ventricular aneurysms.

Variables with significant prognosis - Some variables have negatively influenced CCC prognosis: male gender, cardiac failure, complex ventricular arrhythmias, flutter and atrial fibrillation, ventricular tachycardia, total AV - block and presence of an inactive electrical zone ${ }^{14,38,44,54-56}$

Our results have not shown a higher frequency of events or cardiac death in male patients. Dias' study ${ }^{56}$ in Bambuí has not shown gender predominance in CCC deaths either in $8.3 \%$ of total death in 268 cases.

Atrioventricular block, sinus node dysfunction, neurological mechanism and SVT can be the cause of syncope among chagasic patients ${ }^{13}$. In our study, syncope was not found to be a predictor of events or cardiac death.

No correlation existed between age and occurrence of events or cardiac death in our study. Laranja ${ }^{57}$ analyzed 200 deaths caused by Chagas' disease and found that more than half $(55 \%)$ of the patients died when they were 21 to 40 years old. In another study Mady ${ }^{58}$ analyzed the survival predictors in a total of 104 chagasic men and did not find a relationship between age and death. Our results were similar to those and can be explained by the fact that NSVT was found in all patients, and the prognosis was linked to the occurrence of sustained ventricular arrhythmias.

We found a significant association between ECG conduction disturbance and clinical events, but not between ECG and death. This fact may be the result of the impact of drugs for treatment of heart failure like angiotensin-converting enzyme inhibitors, with a decrease of in mortality ${ }^{59,60}$.

The prognostic value of ventricular dysfunction in CCC is well known ${ }^{14,44,58}$. In our patients the mean ejection fraction was significantly lower in those who died, but this association was not observed for total cardiac events.

The use of ventricular-programmed simulation for risk stratification in patients with dilated cardiomyopathy is controversial. In patients with CCC and complex ventricular arrhythmias, only $2^{18,20}$ of $5^{17,21}$ reports published in the literature, demonstrate a relationship between inducible ventricular arrhythmias with a prognosis during clinical follow-up.

Mendonça ${ }^{14}$ determined that in 60 chagasic patients with NSVT with mean ejection fraction of $41 \%$, the inducible rate was 20\%. During a mean follow-up time of 49 months, cardiac events and death were higher among the inducible patients. Our results have shown a significant association between event occurrence and SMVT induction, cardiac death and induction, sudden death (SD) and induction and finally between induction and death. Also, logistic rejection showed higher probability of event occurence and cardiac death among inducible patients, with an odds ratio of 2.58 and 2.17, respectively. The four patients in whom ventricular fibrillation was induced had no cardiac events during a mean follow-up of 65 months. Induction of VF in these patients was considered a nonspecific response to programmed ventricular stimulation ${ }^{61}$.

Clinical follow-up - Mortality rates in a heterogeneous population of chagasic patients ranged between 2.8 and $31.1 \%{ }^{54,57,62-66}$. In our study during a mean follow-up of 55.7 months 22 deaths ( $28.2 \%$ ) occurred. Our high mortality rate was due to our high risk patients, all with cardiac disease and NSVT.

During clinical follow-up 7 patients needed a permanent pacemaker; 4 patients had complete AV block and $3 \mathrm{pa}-$ tients had sinus node dysfunction. Patients with $\mathrm{CCC}$ and $\mathrm{AV}$ block have a progressive risk of complete AV block ${ }^{67}$.

Occurrence of spontaneous SMVT during follow-up was also observed in 6 inducible patients and in one noninducible patient. Patients with inducible SMVT have a reentrant circuit and a higher probability of experiencing clinicaly sustained arrhythmias than noninducible patients do ${ }^{68}$.

Life expectancy - Despite the social, economic and clinical importance of CCC and its morbidity and mortality, few studies about the survival of these patients have been conducted.

Mady ${ }^{58}$ studied chagasic patients with heart failure and found survival expectancy rates of $66 \%$ in the first year, $56 \%$ in 3 years, and $48 \%$ in 5 years. Santana (44) has found a survival rate of $48 \%$ in patients with NSVT, and $100 \%$ in those with normal ECG in 7 years of follow-up. In our study, the survival rates were $91.7 \%$ in the first year; $83.8 \%$ in 3 years; $81.9 \%$ in 5 years and $50.6 \%$ in 10 years and induction was the most relevant predictor of survival and occurrence of events in our patients. Differences in survival rates were probably due to noninclusion in our study of patients with decompensated congestive heart failure.

Clinical Implications - Patients with CCC and NSVT with induction of sustained ventricular arrhythmia have a higher incidence of spontaneous SMVT, cardiac events and mortality, sudden death and total mortality than the noninducible group. Careful clinical evaluation and prospective studies may select therapeutic interventions that may benefit patients who are more prone to cardiac events. 


\section{References}

1. Bigger JT, Fleiss JL, Kleiger R, Miller JP, Rolnitzky LM. And the multicenter post-infarction research group. The relationships among ventricular arrhythmias, left ventricular dysfunction, and mortality in the 2 years afther myocardial infarction. Circulation 1984; 69: 250-8.

2. Mukharji J, Rude RF, Poole WK, et al and the Miles Study Group: Risk factors for sudden death after acute myocardial infarction: two-year follow-up. Am J Cardiol 1984; 54: 31-6.

3. Maggioni AP, Zuanetti G, Franzosi MG, et al. Prevalence and prognostic significance of ventricular arrhythmias after acute myocardial infarction in the fibrinolytic era. Circulation 1993; 87: 312-22.

4. Kowey PR, Taylor JE, Marinchak RA, Rials ST. Does programmed stimulation really help in the evaluation of patients with nonsustained ventricular tachycardia? Results of a meta-analysis. Am Heart J 1992; 123: 481-5.

5. Kinder C, Tamburro P, Kopp D, Kall J, Olshansky B, Wilber D. The clinical significance of nonsustained ventricular tachycardia: Current perspectives. PACE 1994; 17: 637-64.

6. Pimenta J, Miranda M, Pereira CB. Electrophysiologic findings in long-term asymptomatic chagasic individuals. Am Heart J 1983; 106: 374-80.

7. Carrasco HA, Mora R, Inglessis G, Contreras JM, Marval J, Fuenmayor A. Estudio de la función del nodo sinusal y de la conducción atrioventricular en pacientes con enfermedad de Chagas. Arch Inst Cardiol Méx 1982; 52: 245-51.

8. Maia IG, Sá RS, Loyolla H, et al. O nódulo atrioventricular na cardiopatia chagásica crônica. Estudo eletrofisiológico. Arq Bras Cardiol 1984; 42: 191-5.

9. Lorga AM, Garzon SAC, Ardito RV, et al. Eletrograma de His na cardiopatia chagásica crônica. IIII: condução $\mathrm{AV}$ juncional basal e com marca-passo atrial. Arq Bras Cardiol 1974; 27(supl. I): 113-8.

10. Sosa EA. Contribuição para o estudo das propriedades eletrofisiológicas do coração na doença de Chagas. Tese de Doutoramento - Faculdade de Medicina da Universidade de São Paulo. São Paulo, 1979: 71p.

11. Benchimol CB. Distúrbios da condução na cardiopatia chagásica crônica. Estudo eletrofisiológico de 81 casos. Ars Curandi Cardiol 1980; 2: 10-25.

12. Maia EG, Monteiro SM, Sá RS, Loyolla H, Sudart PCC, Amino JGC, Peixoto ECS, Neto CD, Dohmann HFJ. Cardiopatia chagásica crônica: estudo eletrofisiológico. Ars Curandi Cardiologia 1983; 5: 38-43.

12a. Barbosa EC, Albanesi $F^{\circ}$ FM, Ginefra P. Avaliação da síncope em pacientes com cardiopatia chagásica crônica. Arq Bras Cardiol 1991; 57: 301-5.

13. Martinelli M, Sosa E, Nishioka S, Scanavacca M, Bellotti G, Pileggi F. Clinical and electrophysiologic features of syncope in chronic chagasic heart disease. J Cardiovasc Electrophysiol 1994; 5: 563-70.

14. Mendonça MA. Avaliação eletrofisiológica da síncope em portadores de cardiopatia chagásica crônica e taquicardia ventricular não sustentada. Tese de doutoramento - Escola Paulista de Medicina. São Paulo, 1994: 112p.

15. Scanavacca MI, Sosa EA, Lee JH, Bellotti G, Pileggi F. Terapêutica empírica com amiodarona em portadores de miocardiopatia chagásica crônica e taquicardia ventricular sustentada. Arq Bras Cardiol 1990; 54: 367-71.

16. De Paola AAV, Gomes JA, Souza IA, Vattimo AC, Guiguer Jr N, MartinezEE. Efficacy of amiodarone in patients with ventricular tachycardia and chronic chagasic cardiomyopathy. J Am Coll Cardiol 1994: 322A.

17. Da Silva AC. Estudo eletrofisiológico em portadores de cardiopatia chagásica crônica com extra-sistolia ventricular. Tese de Doutoramento - Faculdade de Medicina da Universidade de São Paulo. São Paulo, 1984. 69p.

18. De Paola AAV. Estimulação ventricular programada em pacientes com cardiopatia chagásica crônica e taquicardia ventricular. Tese de Livre-Docência - Escola Paulista de Medicina. São Paulo, 1990: 61p.

19. MoreiraD, Gizzi JC, Sierra CA, KusnirC, MoraesLR, Sousa JEMR. Quais as características dos pacientes chagásicos com função ventricular mormal e arritmias ventriculares que necessitam antiarrítmico? Arq Bras Cardiol 1994; 63(supl I): 71.

20. Mendonça A, De Paola AAV, Hara VM, Mehta N, Gondim FAA, Portugal OP. Variáveis clínicas eletrofisiológicas e de função ventricular relacionadas à mortalidade cardíaca em pacientes com cardiopatia chagásica crônica e taquicardia ventricular não sustentada. Arq Bras Cardiol 1994; 63(supl I): 124.

21. Sosa E, Scanavacca M, Cury H, et al. Risk stratification to sustained ventricular tachycardia in chagasic heart disease. Circulation 1994; 90: I-179.

22. Kuller LH. Sudden death - definition and epidemiologic considerations. Prog Cardiovasc Dis 1980; 23: 1

23. Siegel S. Estadistica no Parametrica. México: Ed Trillas, 1975: 346p.

24. Lee LT. Nonparametric methods for comparing survival distribuitions. In: Lee ET. Statitical Methods for Survival Data Analysis. Belmont LLP 1980: 122-56.

25. Wanderley DMV, Corrêa FMA. Epidemiologia da Doença de Chagas. In: Sousa AGMR, Mansur AJ. SOCESP Cardiologia $-2^{\circ}$ volume. São Paulo: Atheneu, 1996: 582-91.
26. Guimarães AC. Aspectos eletrocardiográficos da cardiopatia chagásica. In: Cançado JR, Chuster M. Cardiopatia Chagásica. Rio de Janeiro: Fundação Carlos Chagas, 1995: 141-7.

27. Dias E, Laranja FS, Nóbrega G. Doença de Chagas. Memórias do Instituto Oswaldo Cruz 1945; 42: 520-50.

28. Rosenbaum MB. Chagasic myocardiopathy. Progress in Cardiovascular Disease. 1964; 7: 199-225.

29. Benchimol CB, Ginefra P, Benchimol ARB. Avaliação eletrofisiológica. In: Cançado JR., Chuster M. Cardiopatia Chagásica. Rio de Janeiro: Fundação Carlos Chagas, 1985: 213-22.

30. Moia B, Rosenbaum MB, Hofmann D. Aneurismas ventriculares en la miocarditis cronica chagasica. Rev Argen Cardiol 1955; 22: 113-50

31. Granzotti JA, Marin Neto JA, Gallo Jr L, Manço JC, Rassi A, Amorin DS. Contribuição ao estudo do "aneurisma" de ponta na cardiopatia chagásica crônica. Arq Bras Cardiol 1974; 27: 477-87.

32. Saad EA, Netto MS, Pryzytyk RN, Feres JGF, Souza EA, Abraão C. Estudo hemodinâmico e angiográfico. In: Cançado JR, Chuster M: Cardiopatia Chagásica. Rio de Janeiro: Fundação Carlos Chagas, 1985: 188-212.

33. Albanesi $\mathrm{F}^{\circ} \mathrm{FM}$, Gomes $\mathrm{F}^{\circ} \mathrm{JBM}$. Acometimento da ponta do ventrículo esquerdo na cardiopatia chagásica crônica: Aspectos clínicos e ventriculográficos. Arq Bras Cardiol 1989; 52: 115-20.

34. Saad EA, Salles Neto M, Esquenazi R, Souza APS. Cinecoronariografia seletiva na doença de Chagas e nas miocardiopatias primárias. Estudo comparativo e correlação anátomo-patológica. Arq Bras Cardiol 1969; 22(supl 1): 40.

35. Lorga A, Garzon SAC, Moreira L, et al. Correlação clínico-cineangiocardiográfica em 40 pacientes portadores de doença de Chagas crônica. Arq Bras Cardiol 1978; 25: 69-70.

36. Marin-Neto JA, Simões MV, Ayres-Neto EM, et al. A circulação coronária na cardiopatia chagásica crônica. Rev Soc Cardiol ESP 1994; 4: 156-62.

37. Carrasco HA, Guerreiro L, Parada H, Molina C, Vegas E, Chuecos R. Ventricular arrhytmias and left ventricular myocardial function in chronic chagasic patientes. Int J Cardiol 1990; 28: 35-41.

38. Barretto ACP, ArteagaE, Mady C, Ianni BM, Bellotti G, Pileggi F. Sexo masculino. Fator prognóstico na Doença de Chagas. Arq Bras Cardiol 1993; 60: 225-7.

39. Schulze RA, Strauss HW, Pitt B. Sudden death in the year following myocardial infarction: Relation to ventricular premature contractions in the late hospital phase and left ventricular ejection fraction. Am J Med 1977; 62: 192-9.

40. Califf RM, Mckinnis RA, Burks J, et al. Prognostic implications of ventricular arrhythmias during 24 hour ambulatory monitoring in patients undergoing cardiac catheterization for coronary artery disease. Am J Cardiol 1982; 50: 23-31.

41. Olshausen KV, ShwarzF, Apfelbach J, Pohrig N, Kramer B, Kubler W. Determinants of the incidence and severity of ventricular arrhythmias in aortic valve disease. Am J Cardiol 1983; 51: 1103-9.

42. Huang SK, Messar JV, Dener P. Significance of ventricular tachycardia in idiopathic dilated cardiomyopathy: observations in 35 patients. Am J Cardiol 1983; 51: 507-12.

43. Olshausen K, Schafer A, Mehmel HC, SchwarzF, Senges J, Kubler W. Ventricular arrhythmias in idiopathic dilated cardiomyopathy. Br Heart J 1984; 51: 195-201.

44. Santana OO. Arritmia ventricular e evolução clínica de pacientes na fase crônica da Doença de Chagas. (Tese de Mestrado - Faculdade de Medicina da Universidade Federal da Bahia). Salvador 1987:50 p.

45. Garzon SAC, Lorga AM, Nicolau JC. Eletrocardiografia na cardiopatia chagásica. Rev Soc Cardiol ESP 1994; 4: 133-43

46. Carvalhal SS, Bittencourt LAK, Nogueira EA, Jorge PAR, Curti HJV, Sanches PCR. A lesão apical na cardiopatia chagásica. Arq Bras Cardiol 1980; 35: 171-6.

47. Nogueira EA, Ueti OM. Função Ventricular na Cardiopatia Chagásica. In: Sousa AGMR, Mansur AJ: SOCESP Cardiologia $-2^{\circ}$ volume. São Paulo: Editora Atheneu, 1996: 620-5.

48. El-Sherif N, Turitto G. Complex ventricular arrhythmias and nonsustained ventricular tachycardia: Risk stratification and management. In: EL-Sherif N, Samet P: Cardiac Pacing and Electrophysiology. Philadelphia: WB Saunders, 1991: 217-30.

49. Takehara K, Scanavacca M, Sosa EA, et al. Aspectos anátomo-patológicos do foco de taquicardia ventricular sustentada recorrente da miocardiopatia chagásica crônica. Arq Bras Cardiol 1990; 55: B-68.

50. Milei J, Pesce R, Valero E, Muratore C, Beigelman R, Ferrans VJ. Electrophysiologic-structural correlations in chagasic aneurysms causing malignant arrhythmias. Int J Cardiol 1991; 32: 65-74.

51. Spielman SR, Greenspan AM, Kay HR, et al. Electrophysiologic testing in patients at high risk for sudden cardiac death. I. Nonsustained ventricular tachycardia and abnormal ventricular function. J Am Coll Cardiol 1985; 6: 31-9.52. Buxton AE, Waxman HJ, Marchlinski FE, Josephson ME. Eletrophysiologic 
studies in nonsustained ventricular tachycardia: relation to underlying heart disease. Am J Cardiol 1983; 52: 985-91.

53. De Paola AVV, Horowitz LN, Miyamoto MH, et al. ngiographic and electrophysiologic substrates of ventricular tachycardia in chronic chagasic myocarditis. Am J Cardiol 1990; 65: 360-3.

54. Porto CC. O eletrocardiograma no prognóstico e evolução da doença de Chagas. Arq Bras Cardiol 1964; 17: 313-46.

55. Garzon SAC, Lorga AM, Nicolau JC, Coelho WNC, Machado NCS, Jacob JLB correlações entre alterações eletrocardiográficas e fração de ejeção do VE em chagásicos crônicos considerando anormalidades isoladas e por análise de regressão múltipla. Arq Bras Cardiol 1993; 61(supl II): 130.

56. Dias JCP. Doença de Chagas em Bambuí, Minas Gerais, Brasil. Estudo clínicoepidemiológico a partir da fase aguda. Entre 1940e 1982. Tese de Doutoramento - Universidade Federal de Minas Gerais. Belo Horizonte, 1982: 375 p.

57. Laranja FS, Dias E, Nóbrega G, Miranda A. Chagas' disease. A clinical, epidemiologic and pathologic study. Circulation 1956; 14: 1035-60.

58. Mady C, Cardose RHA, Barretto ACP, Luz PL, Bellotti G, Pileggi F. Survival and predictors of survival in patients with congestive heart failure due to Chagas' cardiomyopathy. Circulation 1994; 90: 3098-102.

59. The Consensus Trial Study Group. Effects of enalapril on mortality in severe congestive heart failure: results of the Cooperative North Scandinavian Enalapril Survival study (CONSENSUS). N Engl J Med 1986; 316: 1429-35.

60. The Solvd Investigators: Effect of the angiotensin converting enzyme inhibitor enelapril on survival in patients with reduced left ventricular ejection fraction and congestive heart failure. N Engl Med 1991; 325: 293-302.

61. El-Sherif N. Polymorphic ventricular tachycardia. In: Podrid PJ, Kowey PR: Cardiac Arrhythmia. Mechanisms, Diagnosis, and Management. : Williams \& Wilkins, 1995: 936-50.

62. Chagas C, VillelaE. Forma Cardíaca da Trypanosomíase Americana. Mem InstOswaldo Cruz 1922; 14: 5-61.

63. Pompeu FR. Estudo longitudinal da doença de Chagas em trabalhadores rurais no Município de Luz, Minas Gerais (1976-1985). Tese de Mestrado - Universidade Federal de Minas Gerais. Belo Horizonte, 1990: 129p.

64. Brasil A. Evolução e prognóstico da doença de Chagas. Arq Bras Cardiol 1965; 18: $365-80$.

65. Macedo VO. Influência da exposição à reinfecção na evolução da doença de Chagas (estudo longitudinal de cinco anos). Tese de Livre-Docência - Universidade Federal do Rio de Janeiro. Rio de Janeiro, 1973: 125p.

66. Pereira JB, Willcot HP, Coura JR. Morbidade da doença de Chagas. III- Estudo longitudinal, de seis anos, em Virgem da Lapa, MG, Brasil. Mem Inst Oswaldo Cruz 1985; 80: 63-71.

67. Scanavacca M, Sosa E. Estudo eletrofisiológico na cardiopatia chagásica crônica. Rev Soc Cardiol ESP 1994; 4: 168-76.

68. Buxton AE. Nonsustained ventricular tachycardia: clinical significance and mechanisms. In: Podrid PJ, Kowey PR. Cardiac Arrhythmia - Mechanisms, Diagnosis, and Management. : Willliams \& Wilkins, 1995: 257-72. 